\title{
sciendo
}

\section{THE PROXIMATE COMPOSITION, AMINO ACID PROFILE AND CHEMICAL INDICES IN FIVE FRESHWATER FISHES FROM TIGA DAM RESERVOIR, NIGERIA}

\author{
Audu Michael Elaigwu* \\ Department of Fisheries and Aquaculture Federal University Dutsinma Nigeria \\ *Corresponding Author, Email: aelaigwu@fudutsinma.edu.ng
}

\section{ARTICLE INFO}

Received: 1 August 2018

Accepted: 11 February 2019

\begin{abstract}
The study assesses the proximate composition, amino acid profile and its content and chemical indices of the sun-dried Schilbe mystus, Bagrus bayad, Oreochromis niloticus, Clarias anguillaris and Petrocephalus bane bane from Tiga Dam Reservoir, Nigeria. The proximate composition varied significantly $(p<0.05)$ in all five species of fish and these ranged as follows: Moisture (4.79 - 9.52 g/100 g), Crude Protein (42.20 - 57.71 g/100 g), Ash Content (0.90 - 12.51 g/100 g), Ether Extract (3.41 - 9.93 g/100 g), Crude Fibre (0.62 - $5.08 \mathrm{~g} / 100 \mathrm{~g})$, Nitrogen Free Extract $(12.28$ - $42.70 \mathrm{~g} / 100$ g) and Dry Matter (90.48 - $95.21 \mathrm{~g} / 100 \mathrm{~g})$. The amino acid also differed significantly $(p<0.05)$. The nine essential amino acids found in the five species of fish were Lysine (4.21 - $6.34 \mathrm{~g} / 100 \mathrm{~g})$, Histidine (1.96 - 4.30 $\mathrm{g} / 100 \mathrm{~g})$, Arginine (5.80 - $8.21 \mathrm{~g} / 100 \mathrm{~g})$, Threonine (1.93 - $5.05 \mathrm{~g} / 100 \mathrm{~g})$, Valine (2.91 - $5.53 \mathrm{~g} / 100 \mathrm{~g})$, Methionine (1.74 - $3.80 \mathrm{~g} / 100 \mathrm{~g})$, Isoleucine (2.04 - $3.37 \mathrm{~g} / 100 \mathrm{~g})$, Leucine (3.64 - $7.18 \mathrm{~g} / 100 \mathrm{~g})$ and Phynylalanine (1.90 - $4.23 \mathrm{~g} / 100 \mathrm{~g})$. Whereas, the eight non-essential amino acids included: Serine (2.12 - $5.22 \mathrm{~g} / 100 \mathrm{~g})$, Glutamic acid (13.24 - $16.30 \mathrm{~g} / 100 \mathrm{~g})$, Proline (3.12 - $6.29 \mathrm{~g} / 100 \mathrm{~g})$, Glycine (4.20 - $9.08 \mathrm{~g} / 100 \mathrm{~g})$, Alanine (5.00 - 6.36 $\mathrm{g} / 100 \mathrm{~g})$, Cysteine (0.94 - $1.24 \mathrm{~g} / 100 \mathrm{~g})$, Tyrosine $(2.33$ - $3.33 \mathrm{~g} / 100 \mathrm{~g})$ and Aspartic acid (6.34-11.01 g/100 g). P. bane bane was first in terms of crude protein; S. mystus had the highest lipid and essential amino acid content. Also, $C$. anguillaris recorded the highest calorific value and best amino acid content. Thus, $P$. bane bane can serve as a source of animal protein to balance deficiencies in humans. Both $S$. mystus and $C$. anguillaris can be used as a nutrient base for high energy food and oil in the food industry.
\end{abstract}

Elaigwu, A. M. (2019): The proximate composition, amino acid profile and chemical indices in five freshwater fishes. Croatian Journal of Fisheries, 77, 87-92. DOI: 10.2478/cjf-2019-0009. 


\section{INTRODUCTION}

Fishes are highly favoured by many over other animals in terms of its low collagen of flesh, low level of cholesterol and good flavour (Eyo, 2001). On the basis of availability and palatability, fish is mostly eaten by a considerable number of people as a source of animal protein (Foran et al., 2005). Fishes are sources of animal protein found in many low income homes even in metropolitan areas (Bene and Heck, 2005). In Nigeria, agricultural sector engages up to $70 \%$ of employees and fish plays a vital role as it accounts for $50 \%$ of total animal protein consumed by larger percentage of the populace (FDF, 2009). Components of proximate analysis from fish carcass include ash, lipids, protein, crude fibre and Nitrogen Free Extract. This analysis is performed on fishes to ensure they meet specific and nutrient requirements (Watermann, 2000, Anon, 2000). Fish, like most animals, contain reasonable quantity of amino acids, especially lysine which is known to be in low quantity in cereals. Thus, protein from fish could serve well in augmenting total protein profile in most combinations of food of carbohydrate origin (FAO, 2005). Fish has been recognized as a very significant supply of animal protein and most of the necessary nutrients in human food (Fawole et al., 2007). According to Oladipo and Bankole (2013), there is a need for comprehensive information on the level of nutrient content in fishes mostly found on the dining table of the less privileged across the third world nations of Africa and Asia. In Africa alone, over $60 \%$ of infants below the age of five die annually due to ProteinEnergy Malnutrition (Bene and Heck, 2005). Also similar analysis of the nutrient level of $M$. electricus, T. guineensis and C. gariepinus were conducted (Adeniyi et al., 2012). The study was conducted to determine the proximate composition, amino acid profile and its values in the selected five species of fishes.

\section{MATERIALS AND METHODS}

Five selected fishes - Schilbe mystus, Bagrus bayad, Oreochromis niloticus, Clarias anguillaris and Petrocephalus bane bane - were bought from Tiga Dam Reservoir landing site and were then identified using fish identification key (Olaosebikan and Aminu, 2013), beheaded, degutted and properly washed with table water and were sun-dried for 72 hours at the atmospheric temperature range of $24^{\circ} \mathrm{C}-35^{\circ} \mathrm{C}$, followed by grinding of all fishes using a kitchen blender. The proximate analyses of the fishes sampled were performed in three replicates at the University of Jos biochemistry laboratory, in accordance to the procedure in AOAC (2006).

Calorific values of crude protein, crude lipid and Nitrogen Free Extract (NFE) were calculated using the standard conversion factors (Winberg, 1991):

$$
\begin{aligned}
& \mathrm{a}-\text { crude protein }=\text { protein }(\mathrm{g} / 100 \mathrm{~g}) \times 5.5 \mathrm{kcal} / \mathrm{g} \\
& \mathrm{b}-\text { crude lipid }=\text { amount of lipid }(\mathrm{g} / 100 \mathrm{~g}) \times 9.5 \mathrm{kcal} / \mathrm{g}
\end{aligned}
$$
(2)

$\mathrm{c}-\mathrm{NFE}=$ carbohydrate $(\mathrm{g} / 100 \mathrm{~g}) \times 4.1 \mathrm{kcal} / \mathrm{g}$

Total Calorific Value $=\mathrm{a}+\mathrm{b}+\mathrm{c}$

The Amino Acid profile in the fishes sampled was determined in three replicates using methods described by Benitez (1989). The known sample was dried to constant weight, defatted, hydrolyzed, evaporated in a rotary evaporator and loaded into the Technicon Sequential Multi-sample Amino Acid Analyzer (TSM). The sample was defatted using chloroform/methanol mixture of ratio 2:1. About $4 \mathrm{~g}$ of the sample was put in the extraction thimble and extracted for 15 hours in soxhlet extraction apparatus (AOAC, 2006).

The Essential Amino Acid Index (EAAI), Essential to Nonessential Amino Acid (E:N) and Essential Amino acid per gram Total Nitrogen (E:T) were calculated in accordance with the FAO/WHO Pattern (1973):

\section{$\mathrm{EAAI}=($ Essential Amino acid $(\mathrm{g})) /($ Essential Amino acid of whole hen egg)

$\mathrm{E}: \mathrm{N}=$ (Ratio Essential Amino acid (g)) / (Ratio Nonessential Amino acid)

$\mathrm{E}: \mathrm{T}=($ Essential Amino acid $(\mathrm{g}) \times 100) /($ Total Nitrogen $)$ (7)

Statistical Package for the Social Sciences (SPSS) 20, a software package, was employed for the statistical analysis. Both data for proximate composition and amino acid profile were subjected to Analysis of Variance (ANOVA) and Duncan Multiple Range test was used to separate means at $5 \%$, and significant differences were observed (Duncan, 1955).

\section{RESULTS}

The mean proximate composition, calorific values and ANOVA in five selected fish samples are presented in Table 1.

The five selected fishes were greatly different on the basis of their distinct average proximate composition and calorific values. The moisture content value differed significantly $(p<0.05)$.

The mean values ranged between 4.79 to $9.52 \mathrm{~g} / 100 \mathrm{~g}$ for Schilbe mystus and Oreochromis niloticus, respectively. Observing the moisture content value, fish samples were ranked in the following order: $O$. niloticus $>B$. bayad $>C$. anguillaries $>P$. bane bane $>S$. mystus. But in ranking based on ether extract, reverse was the case as $S$. mystus led with $9.93 \mathrm{~g} / 100 \mathrm{~g}$ and at the bottom was B. bayad with 
Table 1. Mean proximate composition and calorific value in five fish samples

\begin{tabular}{|c|c|c|c|c|c|}
\hline $\begin{array}{c}\text { Proximate composition } \\
(\mathrm{g} / 100 \mathrm{~g}) \\
\end{array}$ & Schilbe mystus & Bagrus bayad & $\begin{array}{c}\text { Oreochromis } \\
\text { niloticus }\end{array}$ & Clarias anguillaris & $\begin{array}{c}\text { Petrocephalus bane } \\
\text { bane }\end{array}$ \\
\hline $\mathrm{MC}$ & $4.79 \pm 0.04^{a}$ & $9.19 \pm 0.20^{d}$ & $9.52 \pm 0.24^{d}$ & $7.94 \pm 0.03^{c}$ & $5.48 \pm 0.07^{b}$ \\
\hline $\mathrm{CP}$ & $53.16 \pm 0.17^{c}$ & $47.52 \pm 1.37^{b}$ & $42.20 \pm 1.76^{a}$ & $51.92 \pm 0.12^{c}$ & $57.71 \pm 0.41^{d}$ \\
\hline ASH & $11.13 \pm 0.08^{c}$ & $0.91 \pm 0.04^{\mathrm{a}}$ & $0.90 \pm 0.05^{a}$ & $3.98 \pm 0.12^{\mathrm{b}}$ & $12.51 \pm 0.12^{d}$ \\
\hline $\mathrm{EE}$ & $9.93 \pm 0.10^{d}$ & $3.41 \pm 0.09^{\mathrm{a}}$ & $3.72 \pm 0.08^{\mathrm{a}}$ & $7.92 \pm 0.20^{c}$ & $6.94 \pm 0.11^{\mathrm{b}}$ \\
\hline $\mathrm{CF}$ & $3.09 \pm 0.10^{c}$ & $1.06 \pm 0.06^{b}$ & $0.96 \pm 0.06^{b}$ & $0.62 \pm 0.05^{\mathrm{a}}$ & $5.08 \pm 0.08^{d}$ \\
\hline NFE & $17.90 \pm 0.28^{b}$ & $37.91 \pm 1.24^{d}$ & $42.70 \pm 1.69^{e}$ & $27.62 \pm 0.28^{c}$ & $12.28 \pm 0.46^{\mathrm{a}}$ \\
\hline DM & $95.21 \pm 0.04^{d}$ & $90.81 \pm 0.21^{\mathrm{a}}$ & $90.48 \pm 0.24^{a}$ & $92.06 \pm 0.03^{b}$ & $94.52 \pm 0.07^{c}$ \\
\hline TCV & 460.11 & 449.19 & 442.51 & 474.04 & 433.68 \\
\hline
\end{tabular}

* Means \pm S.E within a row followed by different alphabets are significantly different ( $p<0.05)$. MC: Moisture Content, CP: Crude Protein, ASH: Ash Content, EE: Ether Extract, CF: Crude Fibre, NFE: Nitrogen Free Extract, DM: Dry Matter TCV: Total Calorific Value.

$3.41 \mathrm{~g} / 100 \mathrm{~g}$. Similarly, S. mystus having $95.21 \mathrm{~g} / 100 \mathrm{~g}$ was the highest in terms of the dry matter, whereas 0 . niloticus with $90.48 \mathrm{~g} / 100 \mathrm{~g}$ was at the bottom. The crude protein and ash contents in all the fishes followed similar pattern as $P$. bane bane led in both cases with 57.71 $\mathrm{g} / 100 \mathrm{~g}$ and $12.51 \mathrm{~g} / 100 \mathrm{~g}$, respectively, while 0 . niloticus had the least values of $42.20 \mathrm{~g} / 100 \mathrm{~g}$ and $0.90 \mathrm{~g} / 100 \mathrm{~g}$, respectively.

There is also a similarity in the evaluation of total calorific value and nitrogen free extract, where in both scenarios $P$. bane bane had the least values of 433.68 and $12.28 \mathrm{~g} / 100$ g, respectively.

The amino acid content of the five selected fish samples and FAO/WHO pattern are reported in Table 2. The five selected fishes were different in terms of their amino acid content and the FAO/WHO pattern. Under the essential amino acid, $C$. anguillaris value of $6.34 \pm 0.04$ was the only fish that met the FAO/WHO pattern for lysine; $B$. bayad and $C$. anguillaris values of $4.30 \pm 0.28$ and $3.28 \pm 0.09$, respectively, also met the standards for histidine.

For arginine all the five selected fishes met the values for FAO/WHO pattern, however, $C$. anguillaris value of $5.05 \pm 0.06$ was the only one that fell within the standards for threonine. S. mystus and P. bane bane with $5.53 \pm 0.04$ and 5.14 \pm 0.07 , respectively, fell within standard values for valine. Except for 0 . niloticus, the other four fishes met the standard values for methionine, but none of the five fishes met the value for FAO/WHO pattern for isoleucine. S. mystus and C. anguillaris values of $7.06 \pm 0.10$ and 7.18 \pm 0.10 , respectively, fell within the standards for leucine. Likewise, all the five fishes fell within the standard values for phynylalanine. As for non-essential amino acids, only $B$. bayad out of the five fishes did not meet the standard values for aspartic acid. But none of the fishes met the value for FAO/WHO pattern for serine, proline and cysteine. But for glutamic acid B. bayad, O. niloticus and $C$. anguillaris values fell within the standards. Likewise, $B$. bayad and $C$. anguillaris fell within the standard values for both alanine and tyrosine. For glycine all five fishes fell within the standard values.

The chemical indices of the five fish samples are reported in Table 3. All the fish samples had a good appraisal on the basis of WHO reference values for the three chemical indices. S. mystus and C. anguillaris values of essential amino acid index (EAAI) were little above WHO reference value of 100 . But $B$. bayad and $P$. bane bane values of 92 and 95, respectively, for EAAl were slightly short of the standard. As for the ratio of essential amino acid to nonessential amino acid (E:N), all of the five fish values were within the WHO Reference value 1 . However, four out of five fishes had value 16 as ratio of essential amino acid per gram total nitrogen ( $\mathrm{E}: \mathrm{T})$, with an exception of $S$. mystus which had value 18 on the basis of E:T; all of the five fish samples did not meet WHO Reference value 50 .

\section{DISCUSSION}

The moisture content value was low in this study (4.79 to $9.52 \mathrm{~g} / 100 \mathrm{~g})$. The reason is that the proximate composition analysis was based on dry matter. This value fell within the range of less than $10 \mathrm{~g} / 100 \mathrm{~g}$ as reported for smoke-dried fish by several authors. Effiong and Fakunle (2011) recorded $8.80 \mathrm{~g} / 100 \mathrm{~g}$ in Bagrus bayad, $10.12 \mathrm{~g} / 100 \mathrm{~g}$ in Oreochromis niloticus and $6.60 \mathrm{~g} / 100$ $\mathrm{g}$ in Clarias gariepinus. Fawole et al. (2007) recorded $7.90 \mathrm{~g} / 100 \mathrm{~g}$ in Heterotis niloticus, 7.07 to $11.14 \mathrm{~g} / 100$ $\mathrm{g}$ in Chrysichtys nigrodigitatus and $5.80 \mathrm{~g} / 100 \mathrm{~g}$ in Sarotherodon galilaeus. But when moisture content in fish is too high, it could promote microbial activities that cause spoilage, leading to the breakdown of unsaturated fats and reduced fish shelf life or time of storage (Omolara and Omotayo, 2008). In this study the moisture content value was lowest for Schilbe mystus (4.79 g/100 g), while Oreochromis niloticus $(9.52 \mathrm{~g} / 100 \mathrm{~g})$ had the highest moisture content value. On the basis of longer shelf life, Schilbe mystus will be chosen first. While Oreochromis niloticus will be the least to be considered.

The crude protein value of 42.20 to $57.71 \mathrm{~g} / 100 \mathrm{~g}$ was in conformity with contemporary work where fish samples with low moisture and high fats possessed a high value of crude protein (Steffens, 2006). The mean value in 
Table 2. The amino acid content of five fish samples and FAO/WHO pattern

\begin{tabular}{|c|c|c|c|c|c|c|}
\hline $\begin{array}{c}\text { Amino Acid } \\
\text { (g/100 g protein) }\end{array}$ & Schilbe mystus & Bagrus bayad & $\begin{array}{c}\text { Oreochromis } \\
\text { niloticus }\end{array}$ & Clarias anguillaris & $\begin{array}{c}\text { Petrocephalus } \\
\text { bane bane }\end{array}$ & FAO/WHO Pattern \\
\hline \multicolumn{7}{|l|}{ EAA } \\
\hline Lysine & $4.90 \pm 0.07^{b}$ & $4.76 \pm 0.12^{b}$ & $4.21 \pm 0.01^{\mathrm{a}}$ & $6.34 \pm 0.04^{c}$ & $4.24 \pm 0.10^{\mathrm{a}}$ & 5.40 \\
\hline Histidine & $2.28 \pm 0.10^{\mathrm{a}}$ & $4.30 \pm 0.28^{c}$ & $2.00 \pm 0.01^{\mathrm{a}}$ & $3.28 \pm 0.09^{b}$ & $1.96 \pm 0.04^{\mathrm{a}}$ & 2.50 \\
\hline Arginine & $6.86 \pm 0.17^{b}$ & $8.21 \pm 0.12^{c}$ & $6.13 \pm 0.04^{\mathrm{a}}$ & $6.82 \pm 0.16^{b}$ & $5.80 \pm 0.15^{\mathrm{a}}$ & 5.20 \\
\hline Threonine & $2.20 \pm 0.11^{b}$ & $2.36 \pm 0.03^{b}$ & $2.23 \pm 0.04^{b}$ & $5.05 \pm 0.06^{c}$ & $1.93 \pm 0.08^{\mathrm{a}}$ & 4.00 \\
\hline Valine & $5.53 \pm 0.04^{e}$ & $2.91 \pm 0.08^{\mathrm{a}}$ & $4.00 \pm 0.02^{b}$ & $4.34 \pm 0.12^{c}$ & $5.14 \pm 0.07^{d}$ & 5.00 \\
\hline Methionine & $3.80 \pm 0.08^{d}$ & $2.00 \pm 0.05^{a}$ & $1.74 \pm 0.12^{\mathrm{a}}$ & $2.34 \pm 0.11^{b}$ & $3.24 \pm 0.05^{c}$ & 2.00 \\
\hline Isoleucine & $3.37 \pm 0.05^{\mathrm{e}}$ & $2.31 \pm 0.02^{b}$ & $2.04 \pm 0.04^{\mathrm{a}}$ & $2.74 \pm 0.15^{c}$ & $3.09 \pm 0.04^{d}$ & 4.00 \\
\hline Leucine & $7.06 \pm 0.10^{d}$ & $4.44 \pm 0.04^{b}$ & $3.64 \pm 0.13^{\mathrm{a}}$ & $7.18 \pm 0.10^{d}$ & $6.77 \pm 0.15^{c}$ & 7.00 \\
\hline Phynylalanine & $4.23 \pm 0.04^{c}$ & $3.82 \pm 0.05^{b}$ & $1.90 \pm 0.08^{\mathrm{a}}$ & $4.19 \pm 0.15^{c}$ & $3.77 \pm 0.14^{b}$ & 3.05 \\
\hline \multicolumn{7}{|l|}{ NEAA } \\
\hline Aspartic acid & $8.40 \pm 0.08^{c}$ & $6.34 \pm 0.08^{\mathrm{a}}$ & $10.29 \pm 0.07^{d}$ & $11.01 \pm 0.03^{\mathrm{e}}$ & $8.01 \pm 0.02^{b}$ & 7.70 \\
\hline Serine & $2.74 \pm 0.10^{b}$ & $2.12 \pm 0.06^{\mathrm{a}}$ & $3.03 \pm 0.06^{b}$ & $5.22 \pm 0.13^{c}$ & $2.28 \pm 0.12^{\mathrm{a}}$ & 7.70 \\
\hline Glutamic acid & $14.69 \pm 0.11^{b}$ & $16.30 \pm 0.10^{\mathrm{e}}$ & $15.92 \pm 0.07^{d}$ & $15.45 \pm 0.03^{c}$ & $13.24 \pm 0.07^{a}$ & 14.70 \\
\hline Proline & $4.55 \pm 0.14^{c}$ & $3.12 \pm 0.05^{\mathrm{a}}$ & $3.93 \pm 0.15^{b}$ & $6.29 \pm 0.20^{d}$ & $4.21 \pm 0.03^{c}$ & 10.70 \\
\hline Glycine & $5.03 \pm 0.06^{c}$ & $4.64 \pm 0.05^{b}$ & $4.20 \pm 0.08^{\mathrm{a}}$ & $9.08 \pm 0.10^{d}$ & $4.87 \pm 0.10^{c}$ & 2.20 \\
\hline Alanine & $5.43 \pm 0.06^{b}$ & $6.29 \pm 0.04^{d}$ & $5.80 \pm 0.12^{c}$ & $6.36 \pm 0.04^{d}$ & $5.00 \pm 0.11^{\mathrm{a}}$ & 6.10 \\
\hline Cystine & $1.24 \pm 0.04^{b}$ & $0.94 \pm 0.04^{\mathrm{a}}$ & $1.21 \pm 0.03^{b}$ & $1.13 \pm 0.11^{b}$ & $1.05 \pm 0.04^{\mathrm{a}}$ & 3.00 \\
\hline Tyrosine & $2.91 \pm 0.06^{b}$ & $3.33 \pm 0.07^{c}$ & $2.71 \pm 0.11 b$ & $3.31 \pm 0.09^{c}$ & $2.33 \pm 0.03^{a}$ & 3.05 \\
\hline
\end{tabular}

*Means $\pm S$.E within a row followed by different alphabets are significantly different ( $<<0.05)$. FAO/WHO (1973), EAA: Essential Amino Acid, NEAA Non-Essential Amino Acid.

this study was supported by work of Mohammad et al. (2011) which reported crude protein of $44.28 \mathrm{~g} / 100 \mathrm{~g}$ in Heterotis niloticus, $38.40 \mathrm{~g} / 100 \mathrm{~g}$ in Serotherondon galilaeus and $41.28 \mathrm{~g} / 100 \mathrm{~g}$ in Clarias anguillaris. On the basis of the crude protein value, Petrocephalus bane bane $(57.71 \mathrm{~g} / 100 \mathrm{~g})$ will be considered first out of the five species of fish. However, Oreochromis niloticus (42.20 $\mathrm{g} / 100 \mathrm{~g}$ ) that had the lowest value of crude protein will be the least likely to be selected. On the basis of the crude protein value, fishes sampled were ranked in the following order: P. bane bane $>S$. mystus $>B$. bayad $>O$. niloticus $>C$. anguillaris. In comparison with other sources of protein, the results were relatively on the high side for lamb, mackerel, beef, oyster and pork (Eyo, 2001). On the basis of macro-nutrient in fish, values of the protein and fat are used to determine the nutritional base of each species (Aberoumad and Pourshafi, 2010).

The disparity in the ash content value of 0.90 to $12.51 \mathrm{~g} / 100 \mathrm{~g}$ was observed due to differences in the environment, peculiar seasons, the quantity and value of food consumed and the level of demand for energy needs (Murray and Burt, 2009). The ash content value was higher in comparison to the range of 0.41 to 1.35 $\mathrm{g} / 100 \mathrm{~g}$ as reported for $C$. citharus, $C$. anguillaris and Hemisynodontis membranaceus (Effiong and Mohammed, 2008). Petrocephalus bane bane $(12.51 \mathrm{~g} / 100 \mathrm{~g})$ had the highest value of ash and will be the first to be chosen in terms of ash content. But Oreochromis niloticus (0.90 $\mathrm{g} / 100 \mathrm{~g}$ ) will be the least to be considered in regard to ash content. On the basis of ash content, fishes sampled were ranked in the following order: P. bane bane $>S$. mystus $>C$. anguillaris $>B$. bayad $>O$. niloticus. The differences noticed in the ash content value could be a result of obvious disparity in species of fish sampled. Also, the ether extract value of 3.41 to $9.93 \mathrm{~g} / 100 \mathrm{~g}$ signified they were all fatty fishes. Schilbe mystus $(9.93 \mathrm{~g} / 100 \mathrm{~g}$ ) had the highest ether extract and was the first to be accepted in terms of the ether extract value, while Bagrus bayad ( $3.41 \mathrm{~g} / 100 \mathrm{~g}$ ) with the lowest ether extract value will be the least likely to be chosen. On the basis of the ether extract value, fishes sampled were ranked in the following manner: $S$. mystus $>C$. anguillaris $>P$. bane bane $>O$. niloticus $>B$. bayad. But $O$. niloticus and B. bayad values which fell below 5 $\mathrm{g} / 100 \mathrm{~g}$ could be grouped under low fat. On the basis of the ether extract value, these freshwater fishes could serve as a good sources of fat (Osibona et al., 2009).

The crude fibre value of 0.62 to $5.08 \mathrm{~g} / 100 \mathrm{~g}$ was low in comparison with the value of 3.42 to $14.38 \mathrm{~g} / 100 \mathrm{~g}$ of crude fibre reported for $O$. niloticus (Fawole et al., 2007). Nevertheless, in this study S. mystus $(3.09 \mathrm{~g} / 100 \mathrm{~g}), P$. bane bane $(5.08 \mathrm{~g} / 100 \mathrm{~g})$ and B. bayad $(1.06 \mathrm{~g} / 100 \mathrm{~g})$ had relatively good roughages as seen in their individual crude fibre values. On the basis of the crude fibre value, fishes sampled were ranked in the following order: P. bane 
Table 3. The chemical indices of five fish samples

\begin{tabular}{|c|c|c|c|c|c|c|}
\hline Chemical Indices & Schilbe mystus & Bagrus bayad & $\begin{array}{c}\text { Oreochromis } \\
\text { niloticus }\end{array}$ & Clarias anguillaris & $\begin{array}{c}\text { Petrocephalus } \\
\text { bane bane }\end{array}$ & WHO ref. value \\
\hline EAAI & 105 & 92 & 74 & 110 & 95 & 100 \\
\hline $\mathrm{E}: \mathrm{N}$ & 0.89 & 0.81 & 0.60 & 0.72 & 0.88 & 1 \\
\hline $\mathrm{E}: \mathrm{T}$ & 18 & 16 & 16 & 16 & 16 & 50 \\
\hline
\end{tabular}

*EAAl: Essential Amino Acid Index, E:N: Essential to Non-essential Amino Acid, E:T: Essential Amino Acid per gram Total nitrogen, FAO/WHO (1973)

bane $>S$. mystus $>$ B. bayad $>0$. niloticus $>$ C. anguillaris. Likewise, the nitrogen free extract value of 12.28 to 42.70 $\mathrm{g} / 100 \mathrm{~g}$ was supported by the findings of Oyelese (2006) who reported the nitrogen free extract value of 8.65 to $54.11 \mathrm{~g} / 100 \mathrm{~g}$ in 0 . niloticus, and the work of Onyia et al. (2010) where the nitrogen free extract value of 1.50 to $46.02 \mathrm{~g} / 100 \mathrm{~g}$ was reported for O. niloticus. Oreochromis niloticus (42.70 g/100 g) with the highest nitrogen free extract will be the first to be selected in terms of the nitrogen free extract value. But the nitrogen free extract was lowest for Petrocephalus bane bane (12.28 g/100 $\mathrm{g})$, thus will be the least likely to be chosen in terms of nitrogen free extract. On the basis of the nitrogen free extract value, fishes sampled were ranked in the following order: $O$. niloticue $>$ C. anguillaris $>$ B. bayad $>S$. mystus $>P$. bane bane.

The total calorific value (TCV) provides information on the energy content of the sampled fishes in kilocalorie per gram (kcal/g). The total calorific value was lowest for Petrocephalus bane bane (433.68 kcal/g), whereas Clarias anguillaris (474.04 kcl/g) had the highest total calorific value. On the basis of total calorific value, fishes sampled were ranked in the following order: $C$. anguillaris $>S$. mystus $>B$. bayad $>0$. niloticus $>P$. bane bane.

The amino acid value of 0.94 to $16.30 \mathrm{~g} / 100 \mathrm{~g}$ was encouraging. On the basis of amino acid, the mean values for the lysine, leucine, aspartic acid and glutamic acid were supported by ranking in the order of magnitude (Portz and Cyrino, 2003). The essential amino acids cannot be produced naturally by living organisms and this supports the reason why they must be obtained from various diets consumed by living organisms. Out of the seventeen amino acids recorded in sampled fishes, the nine essential amino acids include: Lysine, Histidine, Arginine, Threonine, Valine, Methionine, Isoleucine, Leucine and Phynylalanine. Also the eight non-essential amino acids recorded include: Aspartic acid, Serine, Glutamic acid, Proline, Glycine, Alanine, Cystine and Tyrosine. The Essential Amino Acid Index (EAAI) provided information on the quality of the protein content in the fishes sampled. Clarias anguillaris (110) had the highest EAAl value and will be the first to be selected on the basis of the WHO Reference value (EAAI). But Oreochromis niloticus (74), having the lowest EAAI value, will be the least likely to be chosen on the grounds of the WHO standard. On the grounds of the WHO Reference value (EAAI), fishes sampled were ranked in the following order: $C$. anguillaris $>S$. mystus $>P$. bane bane $>B$. bayad $>0$. niloticus.

The Essential Amino Acid to Non-essential Amino Acid $(E: N)$ provided information on the ratio of the essential amino acid to non-essential amino acid. Schilbe mystus (0.89) had the highest $(E: N)$ value and will be the first to be selected on the grounds of the WHO standard, while Oreochromis niloticus (0.60), having the lowest $(E: N)$ value, will be the least likely to be chosen on the grounds of the WHO standard. On the basis of the WHO Reference value (E:N), fishes sampled were ranked in the following manner: S. mystus $>P$. bane bane $>B$. bayad $>C$. anguillaris $>0$. niloticus.

The Essential Amino Acid per gram total nitrogen ( $E: T)$ provided information on the quantity of amino acid obtained from a given nitrogen. Schilbe mystus (18) had the highest $(E: T)$ value and will be the first to be chosen against other fishes on the grounds of the WHO standard. However, the other four fish species had the same value of (16) (E:T).

\section{CONCLUSION}

This study showed that the proximate composition was significantly different $(\mathrm{p}<0.05)$. Petrocephalus bane bane recorded the highest protein value and thus was considered first in terms of the crude protein value. Likewise, Schilbe mystus had the highest lipid value and so occupied the first position on the grounds of lipid value. Similarly, Clarias anguillaris having the highest calorific value was selected first on the basis of the total calorific value. The amino acid of sampled fishes varied significantly $(p<0.05)$. A good amino acid Clarias anguillaris was the first to be chosen on the basis of the WHO Reference value, whereas for a higher quantity of essential amino acid, Schilbe mystus maintained the first position in terms of WHO Reference value. Also, Petrocephalus bane bane could be adopted as a source of animal protein and macronutrients, which would help balance up the deficiencies in humans. Likewise, Schilbe mystus and Clarias anguillaris could serve as a nutrient base for high energy food and fish oil in the food industry. 


\section{SAŽETAK}

\section{KEMIJSKI SASTAV I AMINOKISELINSKI PROFIL PET VRSTA SLATKOVODNIH RIBA IZ AKUMU- LACIJE TIGA, NIGERIJA}

Istraživanje procjenjuje kemijski sastav, profil i sadržaj aminokiselina te kemijske pokazatelje Schilbe mystus, Bagrus bayad, Oreochromis niloticus, Clarias anguillaris i Petrocephalus bane bane iz akumulacije Tiga, Nigerija osušenih na suncu. Neposredni sastav značajno varira kod svih pet vrsta riba kako slijedi: vlaga $(4,79$ - 9,52 g / 100 g), sirovi protein $(42,20-57,71 \mathrm{~g} / 100 \mathrm{~g})$, sadržaj pepela (0,90 - 12,51 g / $100 \mathrm{~g})$, ekstrakt etera $(3,41-9,93 \mathrm{~g} / 100$ g), sirova vlakna (0,62 - 5,08 g/100 g), ekstrakt bez dušika $(12,28-42,70 \mathrm{~g} / 100 \mathrm{~g})$ i suha tvar $(90,48-95,21 \mathrm{~g} / 100$ g). Sadržaj aminokiselina se također značajno razlikovao. Devet esencijalnih aminokiselina pronađenih u pet vrsta riba bile su: lizin $(4,21-6,34 \mathrm{~g} / 100 \mathrm{~g})$, histidin (1,96 - 4,30 $\mathrm{g} / 100 \mathrm{~g})$, arginin $(5,80-8,21 \mathrm{~g} / 100 \mathrm{~g})$, treonin $(1.93-5,05$ $\mathrm{g} / 100 \mathrm{~g})$, valin $(2,91-5,53 \mathrm{~g} / 100 \mathrm{~g})$, metionin $(1,74-3,80$ $\mathrm{g} / 100 \mathrm{~g})$, izoleucin $(2,04-3,37 \mathrm{~g} / 100 \mathrm{~g})$, leucin $(3,64-$ $7,18 \mathrm{~g} / 100 \mathrm{~g})$. i fenilalanin $(1,90-4,23 \mathrm{~g} / 100 \mathrm{~g})$. Osam ne-esencijalnih aminokiselina uključivalo je: serin $(2,12$ $5,22 \mathrm{~g} / 100 \mathrm{~g})$, glutaminsku kiselinu $(13,24-16,30 \mathrm{~g} / 100$ g), prolin $(3,12-6,29 \mathrm{~g} / 100 \mathrm{~g})$, glicin $(4,20-9,08) \cdot \mathrm{g} / 100$ g), alanin $(5,00-6,36 \mathrm{~g} / 100 \mathrm{~g})$, cistein $(0,94-1,24 \mathrm{~g} / 100$ $\mathrm{g})$, tirozin $(2,33-3,33 \mathrm{~g} / 100 \mathrm{~g})$ i asparaginska kiselina (6,34 - 11,01 g / 100 g). P. bane bane je sadržavala najviše sirovog proteina; $S$. mystus je imala najveći sadržaj lipida i esencijalnih aminokiselina. C. anguillaris je zabilježila najvišu kaloričnu vrijednost i najbolji sadržaj aminokiselina. P. bane bane može poslužiti kao izvor životinjskih proteina u ljudskoj prehrani. S. mystus i C. anguillaris mogu se upotrijebiti kao hranjiva baza za proizvodnju hrane i ulja visoke energije u prehrambenoj industriji.

\section{Ključne riječi: Protein, riba, hranjiv, sadržaj, rezervoar}

\section{REFERENCES}

Aberoumad, A., Pourshafi, K. (2010): Chemical and proximate composition properties of different fish species obtained from Iran. World Journal of. Fish and Marine Science. 2, 3, 237-239.

Adeniyi, S.A., Orjiekwe, C.L., Ehiagbonare, J.E., Josiah, S.J. (2012): Nutritional Composition of three different Fishes (Clarias gariepinus, Malapterurus electricus and Tilapia guineensis). Pakistani Journal of Nutrition. 11, 9, 793-797.

Anon, (2000). Communication from the Commission to the Council and Parliament Conf. (2000) 724 Brussade European Commission, 20.

AOAC (2006). Official Method of Analysis of the Association of Official Analytical Chemist (W. Horwitz Editor) Eighteen Edition, Washington; D. C., AOAC.

Bene, C., Heck, S. (2005): Fish and food security in Africa. NAGA World Fish Centre Quarterly, 28, 3 - 4, 8-13.

Benitez, L. V. (1989): Amino Acid and fatty acid profiles in aquaculture nutrition studies. In S.S. De Silva (ed.) Fish Nutrition Research in Asia. Proceedings of the Third Asian Fish Nutrition Network Meeting. Asian fish. Society Special Publication. Asian Fisheries Society, Manila Philippine, 166.

Effiong, B. N., Fakunle, J. O. (2011): Proximate and mineral composition of some commercially important fishes in Lake Kainji, Nigeria. Journal of Basic Applied Science Research, 1, 12, 2497-2500.

Effiong, B.N., Mohammed, I. (2008): Effect of seasonal variation on the nutritional composition in selected fish species in Lake Kainji. Nigeria. Natural and Science, 6, 2, 1-5.

Eyo, A.A. (2001): Fish processing technology in the tropics. National Institute for Freshwater Fisheries Research. University of Ilorin press, 66-70.

FAO (2005): United Nations Food \& Agriculture Organization, Nutritional elements of fish. FAO, Rome.

FAO/WHO (1973): Energy and Protein requirement. Report of a Joint FAO/WHO Nutrition Report Series. No. 52. FAO ROME Duncan, D.B. (1955): Multiple ranges and multiple F-Test. Biometrics, 11, 1-42.

Fawole, O.O., Ogundiran, M.A., Ayandiran, T.A., Olagunju, O.F. (2007): Proximate and mineral composition in some selected fresh water fishes in Nigeria. Internet Journal of Food Safety, 9, 52-55.

FDF (2009): Nigeria National Aquaculture Strategy. Assisted by FAO. Formally approved by Government. 18.

Foran, J.A., Carpenter, D.O., Hamilton, M.C., Knuth, B.A., Schwager, S.J. (2005): Risk based consumption advice for farmed Atlantic and wild pacific salmon contaminated with dioxins and dioxinlike compounds. Environment and Health Perspective, 33, 552556.

Muhammad, A., Asmar. Z, Abdul R., Shahid, M., Naureen, Q. (2011): Nutritional values of wild and cultivated silver carp (Hypophthalmichtys molitrix) and grass carp (Ctenopharyngodon idella). International Journal of Agriculture and Biology, 210-214.

Murray, J., Burt, J. R. (2009): The composition of fish, Torry Advisory Note No.3, www.fao.org/wairdocs/tan/x5916e/x5916e00.htm.

Oladipo, I.C., Bankole, S.O. (2013): Nutritional and microbial quality of fresh and dried Clarias gariepinus and Oreochromis niloticus. International Journal of Applied Microbiology and Biotechnology, 1, 1-6.

Olaosebikan, B.D., Aminu, R. (2013): Field guide to Nigerian freshwater fishes. Remis Thomas. New Bussa. 1-136.

Omolara, O.O., Omotayo, O.D. (2008): Preliminary Studies on the effect of processing methods on the quality of three commonly consumed marine fishes in Nigeria. Biochemistry Journal, 21, 1-7.

Onyia, L. U., Millam, C., Manu J. M., Allison, D. S. (2010): Proximate and mineral composition of some freshwater in Upper River Benue, Yola, Nigeria. Continental Journal of Food Science and Technology, 4, 1-6.

Osibona, A.O., Kusemiju, K., Akande, G.R. (2009): Proximate composition and fatty acids profile of the African catfish Clarias gariepinus. Acta Satech, 3, 1, 85-89.

Oyelese, O.A. (2006): Implication of carcass quality and condition factor to the processing of some selected freshwater fish family. Journal of Fisheries International, 1, 2-4, 132-135.

Portz, L., Cyrino, J.E.P. (2003). Comparison of the amino acid contents of roe: whole body, muscle tissue and their ratios for largemouth bass Micropterus salmonoides (Lecepede, 1802). Aquaculture Research, 34, 585-592.

Steffens, W. (2006): Freshwater fish-wholesome foodstuffs. Bulgarian Journal of Agricultural Science, 12, 320-328.

Watermann, J. J. (2000): Composition and Quality, fish, Edinburgh, Torry Research Station.

Winberg, G. G. (1971): Symbols, Units and Conversion Factors. In: Studies of Freshwater Productivity. B.P. Section PFB Central Office, London, 148. 